\title{
Mapping Social Media Tools For Sell vs Buy Activities Into Emerging And Developed Markets
}

\author{
David M. Gilfoil, DeSales University, Center Valley, Pennsylvania, USA
}

\begin{abstract}
This paper studies usage patterns of global sellers and buyers using five forms of Web 2.0 social broadcast behaviors - blogging, micro-blogging, social networking, online video, and online photo uploading. A survey and analysis of the number of people using these tools to sell something (sellers), as compared those people using these same tools to buy something (buyers), is conducted on an "emerging" vs "developed" market basis. The data is obtained from an ongoing panel study and is a continuation of research already published in this area. Findings show that the tools are used quite differentially into emerging vs. developed markets. Social networking and micro-blogging platforms are used significantly more in emerging economies (regardless of sell or buy motivation) while the other three tools exhibit no consistent usage differences across economies. Findings also show that these same two platforms are favored for sell activities in emerging economies vs. developed economies. Blogging and micro-blogging are significantly favored tools of choice where buying is the motivation - blogging is favored by emerging economies and micro-blogging is favored by developed economies. Interestingly, photo uploading is the only tool which showed no differential usage across emerging/developed economies for any kind of sell or buy activity. Average sell/buy usage data for each social broadcast behavior is reported for each country in the emerging and developed markets. In order to better understand the eWOM implications of the current market participation conditions, some areas requiring further investigation are suggested.
\end{abstract}

Keywords: eWOM; Viral Marketing; Web 2.0 Global Trends; Social Media Tools; Social Broadcast Behaviors; Blogging; Micro-blogging; Social Networking; Video Uploading; Photo Uploading

\section{INTRODUCTION}

lobal trends and usage patterns of social media platforms are being established and reported in the academic literature. The rapid growth and future potential of online and mobile internet activity in emerging economies - Brazil, Russia, India, and China (known as BRIC countries) and newly industrialized economies like Malaysia and Mexico (known as NICs) - is particularly interesting and compelling to marketers. China, India and other emerging markets throughout the world will account for $75 \%$ of the world's total growth in the next two decades and beyond, according to U.S. Department of Commerce estimates (Cateora et al, 2009). This survey paper is a continuation of research analyzing the global usage of so called Web 2.0 tools as they relate to eWOM (electronic word of mouth) marketing of global products and services (Jobs, 2011; Gilfoil and Jobs, 2011). Findings from Jobs, 2011, suggest that emerging countries, when compared to technologically and economically more developed countries, are adopting micro-blogging services such as Twitter at a significantly greater and faster rate than social networking services such as Facebook. Gilfoil and Jobs (2011), looking at four widely used tools, found among other things, that there are currently more sellers than buyers using these tools for all the countries analyzed (with the exception of China) and that the gaps between sell and buy activities varied widely by specific country. 
This paper studies broader usage patterns of global sellers and buyers using five forms of Web 2.0 social broadcast behaviors - blogging, micro-blogging, social networking, online video, and online photo uploading. Photo uploading behavior was added to the analysis because its commercial value has previously been reviewed and discussed within the context of a business model (Ju, Lee, and Lee, 2008) and more recently been highlighted in prominent social media marketing books (e.g. Scott, 2010). It has also been validated as a successful selling tool in a large scale study of a popular online auction site (Lewis, 2011).

A survey and analysis of the number of people using these tools to sell something (sellers) vs. those people using these same tools to buy something (buyers) is conducted on an "emerging" vs. "developed" market basis. The data is obtained from an ongoing panel study and is a continuation of research already published in this area. The goal of this study is threefold: (1) to look closer at the reported global usage patterns of five popular online interactive social media tools (where users indicate they use them to sell or buy goods and services), (2) to identify and discuss any significant usage differences between emerging and developed market economies, and (3) to discuss implications for the future of eWOM marketing using these social media broadcast behaviors.

\section{LITERATURE REVIEW}

Online social media networks are increasingly being recognized as an important source of information influencing the adoption and use of products and services. These online networks and services are a subset of the so called Web 2.0 world. The popularity of the term Web 2.0 is largely credited to Tim O'Reilly who described it as a new form of collaborative Web, a "platform harnessing collective intelligence" (O'Reilly, 2005). Hoegg, Martignoni, Meckel, and Stanoevsla-Slabeva (2006) define Web 2.0 as "the philosophy of mutually maximizing collective intelligence and added value for each participant by formalized and dynamic information sharing and creation" (p.12). Anderson (2007) defines Web 2.0 as a group of technologies that have become deeply associated with the term: blogs, wikis, podcasts, RSS feeds and so on; technologies contributing to a more socially connected Web where everyone is able to add to and edit content. More recently, Constantinides and Fountain (2008) proposed the following definition: "Web 2.0 is a collection of open-source, interactive and user-controlled online applications expanding the experience, knowledge and market power of the users as participants in business and social processes. Web 2.0 supports the creation of informal users' networks, facilitating the flow of ideas and knowledge by allowing the efficient generation, dissemination, sharing and editing/refining of informational content" (p.232).

As previously discussed at length by Jobs (2011) and Gilfoil and Jobs (2011), usage of Web 2.0 for marketing purposes makes great sense. Many have suggested that Web 2.0 can enhance the power of viral marketing (Subramani and Rajagopalan, 2003; Leskovec, Adamic, and Huberman, 2007; Hartline, Mirrokni, and Sundararajan, 2008). Others agree and further suggest that Web 2.0 clearly increases the speed at which consumers share experiences and opinions with progressively larger audiences (Thackeray, Neiger, Hanson, and McKenzie, 2008). A fundamental component of viral marketing is providing tools to make it easier to share information. Web 2.0 social media technology enables marketers to develop interactive Web tools that make it virtually effortless for users to engage in viral marketing by encouraging the user to share feedback, provide comments, rate products, provide reviews, and download items for sharing with friends. To better understand the importance and impact of viral marketing activities in today's global marketplace, Van der Lans, Van Bruggen, Eliashberg, and Wierenga (2010) recently developed a model that predicts how many customers a viral marketing campaign reaches, how this reach evolves, and how it depends on proactive marketing activities.

Word of mouth (WOM) advertising is a process of conveying information from person to person which plays a major role in customer buying decisions (Richins and Root-Shaffer, 1988). In commercial situations, WOM involves consumers sharing attitudes, opinions, or reactions about businesses, products, or services with other people. The term eWOM has been defined as: "a statement made by potential, actual, or former customers about a product or company, which is made available to a multitude of people and institutions via the Internet" (HennigThurau, Gwinner, Walsh, and Gremle, 2004, p. 39). Communication via eWOM manifests itself through Web 2.0 applications such as online discussion forums, electronic bulletin board systems, newsgroups, blogs, review sites, and social networking sites (Goldsmith, 2006). Modern (eWOM) communication, using Web 2.0 applications, clearly transcends the limitations of traditional WOM. Consumers today obtain information related to goods and 
services from a vast, geographically dispersed group of people who have experience with relevant products or services instead of only the few people they know (Ratchford, Talukdar, and Lee, 2001; Lee, Cheung, Lim, and Sia, 2006).

Jalilvand, Esfanani, and Samiei (2011) provide a cursory theoretical framework of eWOM, discuss the significant role it plays in the consumer purchasing decision process, and provide a review of the key challenges and opportunities for companies to reach consumers and to influence their opinions. The authors conclude: "Companies should actively get involved in some online consumer communities and provide all relevant and complete information about their company...Marketers must understand that their customers are going online in increasing numbers and that these consumers are likely influenced by the many sites devoted to the selling or discussion of their products or services" (p.45).

While most discussions of eWOM are of a theoretical nature, some recent empirical studies have been reported. Parise and Guinan (2008), for example, conducted an interview survey of 30 marketing managers and senior executives and concluded that there were four principles which guided managers' marketing actions using Web 2.0: 1) facilitate users in generating content, 2) focus on building a community, 3) ensure authenticity of the message, and 4) look for marketing opportunities through experimentation. Also, Jansen, Zhang, Sobel and Chowdury (2009) recently found micro-blogging (Twitter) to be an effective online tool for customer word of mouth communications, and discuss the implications for corporations using micro-blogging as part of their overall marketing strategy.

Global trends in the patterns of online behavior (using Web 2.0 as a potential eWOM facility) are also starting to be established in the academic literature. Using data from a global panel study, Jobs (2011) and Jobs and Gilfoil (2011) found that developing countries, when compared to technologically and economically developed countries, are adopting micro-blogging services at a significantly greater and relative rate than social networking services. The latter study attempted to explain these divergent usage patterns using Hofstede's cultural dimensions model. In a follow up study, Gilfoil and Jobs (2011) found that there are currently more sellers than buyers using four social media broadcast tools across sixteen individual countries analyzed (with the exception of China) and that the size of the gaps between sell and buy activities varied widely by country. While these individual country sell biased gaps were interesting, the authors suggested that additional research be initiated to investigate sell vs buy motivational usage of a broader set of social media tools with an eye towards mapping these tools (as appropriate sell or buy platforms for marketers or consumers) in emerging and/or developed economies around the globe.

Prior theoretical work by Constantinides, Romero, and Boria (2008) can help us refine the way we think about Web 2.0 usage by marketers and consumers alike. It is helpful, according to Constantinides et al, to think about marketers interacting with consumers using passive and active web marketing tools:

Using Web 2.0 applications as passive marketing tools: Listening-in to the user's voice makes sense assuming that a company or brand is known. Company marketers can listen to the voice of the market in order to be informed not only about changing consumer needs and trends, but also to hear the customer's opinion about competitors or products. Blogs and online forums are the most important potential sources of such information, followed by content communities and social networks.

Using Web 2.0 applications as active marketing tools: Depending on company size, market coverage, and marketing objectives, a company could create (and make available) online tools (e.g. corporate websites, video blogs, blogs, micro-blogs, bulletin boards, content aggregators) that allow users to interact with the firm and other customers, customize their experience, express their creativity either in advertising copies or design of new products, integrate good ideas from customers into the mainstream marketing program, and so on.

The current study is an investigation of (both passive and active) usage of Web 2.0 tools by a panel of active global users (sellers and buyers) from "emerging" and "developed" countries over a two year period. Of primary interest is how study participants use specific Web 2.0 broadcast behaviors (including corporate marketing efforts and consumer ad hoc efforts) to buy and sell products or services. 


\section{Trendstream Global Web Index}

Piskorski and McCall (2010), have constructed a popular visual model of global patterns for social internet adoption using fresh data from the Trendstream Global Web Index (GWI). The GWI is a recurring survey of more than 50,000 users of social platforms in 18 markets over a two year period. It provides raw data on five social broadcast behaviors - blogging, social networking, uploading videos, uploading photos, and micro blogging. Examples of social media websites related to the five broadcast behaviors are depicted in Table 1. The global interest and potential utility of these social media platforms has been widely documented and validated as important forms of marketing communication in both commercial (Forrester Research (2009), TopRank (2011), CMO (2011)) and academic (Weber, (2009), Arminen, (2010) venues.

Table 1. Select Examples Of Social Media Broadcast Providers

\begin{tabular}{|c|c|c|c|c|}
\hline Photo & Social Networking & Video Sharing & Blog & Micro-blog \\
\hline Flickr & Facebook & YouTube & Huffingtonpost & Twitter \\
\hline Fotolog & MySpace & GoogleVideo & Mashable! & Frazr \\
\hline Photobucket & LinkedIn & YahooVideo & Eurogamer & Pownce \\
\hline Shutterfly & Orkut & Dailymotion & BoingBoing & Tumblr \\
\hline Webshots & Hi5 & Blip.tv & Gizmodo & Jaiku \\
\hline Snapfish & Tagged & Flixya & $\begin{array}{c}\text { The International } \\
\text { Student Blog }\end{array}$ & Foursquare \\
\hline
\end{tabular}

The current study utilizes data gathered by Trendstream from countries designated as "emerging" or "developed" economies. It is specifically designed to examine differences in (emerging vs developed economy) user motivations to use these online interactive tools to sell and/or buy goods and services.

\section{METHODS}

\section{Sample}

The data is based on a panel survey commissioned by Trendstream Research utilizing Lightspeed Online Research survey panelists around the world. Trendstream Research is a London based market research company offering advanced analysis of social networking trends. Lightspeed Online Research, Inc. is a private market research and analysis firm located in Basking Ridge, NJ, with offices around the world. This study uses the first 3 panel survey waves released over a year period between July 2009 and July 2010. Wave 1 was released in July 2009. Wave 2 was collected in the second half of 2009 and subsequently released in January 2010. Wave 3 was collected between January 2010 and July 2010 when it was released.

In this study, buyers and sellers who are active users (using broadcast behaviors within 30 days of the survey), are the focal point because they are most relevant to research on motivational usage of social broadcast platforms. Also, in this study, in order to provide social media mapping guidance to global marketers, a full spectrum of broadcast behaviors were studied to discern any unique differences in motivational usage across emerging and developed economies. The number of active sellers and buyers from each country and the tool used is provided in Tables $2 \mathrm{~A}, 2 \mathrm{~B}$, and $2 \mathrm{C}$ (following):

\begin{tabular}{|c|c|c|c|c|c|c|c|c|c|c|c|c|c|c|c|c|}
\hline$\frac{\text { Online }}{\text { Behavior }}$ & USA & Canada & Russia & Nether & France & $\underline{\text { Spain }}$ & Italy & UK & Germany & Mexico & Brazil & Australia & Japan & $\underline{\text { South }}$ & China & India \\
\hline \begin{tabular}{|l|} 
Photo \\
\end{tabular} & 908 & 422 & 448 & 278 & 277 & 396 & 449 & 904 & 331 & 399 & 408 & \begin{tabular}{r|}
294 \\
\end{tabular} & 180 & 401 & \begin{tabular}{|l|}
610 \\
\end{tabular} & 487 \\
\hline Video & 325 & 154 & 301 & 75 & 96 & 163 & 217 & 276 & 89 & 167 & 257 & 91 & 53 & 147 & 290 & 276 \\
\hline \begin{tabular}{|l} 
Social \\
Network
\end{tabular} & 941 & 477 & 365 & 272 & 295 & 359 & 372 & 997 & 342 & 303 & 450 & 300 & 137 & 118 & 276 & 438 \\
\hline Blog & 273 & 109 & 139 & 76 & 96 & 173 & 201 & 197 & 105 & 193 & 156 & 86 & 226 & 301 & 465 & 259 \\
\hline Micro Blog & 150 & 53 & 91 & 26 & 38 & 75 & 128 & 122 & 60 & 103 & 107 & 42 & 74 & 106 & 215 & 183 \\
\hline
\end{tabular}


Table 2b. Wave 2 - January 2010

\begin{tabular}{|c|c|c|c|c|c|c|c|c|c|c|c|c|c|c|c|c|}
\hline$\frac{\text { Online }}{\text { Behavior }}$ & USA & Canada & Russia & Nether & France & Spain & Italy & $\underline{\mathrm{UK}}$ & Germany & Mexico & Brazil & Australia & Japan & $\underline{\text { South }}$ & China & India \\
\hline Photo & 861 & 426 & 449 & 270 & 308 & 427 & 454 & 821 & 322 & 407 & 439 & 307 & 140 & 386 & 548 & 491 \\
\hline Video & 378 & 186 & 328 & 79 & 108 & 188 & 253 & 299 & 85 & 157 & 311 & 117 & 35 & 181 & 341 & 291 \\
\hline $\begin{array}{l}\text { Social } \\
\text { Network }\end{array}$ & 975 & 498 & 393 & 300 & 353 & 427 & 413 & 992 & 260 & 364 & 487 & 335 & 126 & 187 & 461 & 488 \\
\hline Blog & 246 & 121 & 144 & 52 & 79 & 187 & 190 & 191 & 66 & 224 & 160 & 79 & 186 & 288 & 442 & 275 \\
\hline Micro Blog & 136 & 68 & 109 & 23 & 41 & 76 & 115 & 131 & 29 & 113 & 140 & 43 & 60 & 100 & 230 & 174 \\
\hline
\end{tabular}

Table 2c. Wave 3 - July 2010

\begin{tabular}{|c|c|c|c|c|c|c|c|c|c|c|c|c|c|c|c|c|}
\hline$\frac{\text { Online }}{\text { Behavior }}$ & USA & Canada & Russia & Nether & France & Spain & Italy & $\underline{\mathrm{UK}}$ & Germany & Mexico & Brazil & Australia & Japan & $\underline{\text { South }}$ & China & India \\
\hline Photo & 858 & 388 & 419 & 271 & 325 & 436 & 435 & 813 & 277 & 397 & 424 & 295 & 146 & 359 & 566 & 494 \\
\hline Video & 402 & 275 & 318 & 73 & 138 & 211 & 239 & 323 & 101 & 181 & 313 & 137 & 59 & 195 & 331 & 323 \\
\hline $\begin{array}{l}\text { Social } \\
\text { Network }\end{array}$ & 992 & 435 & 447 & 292 & 438 & 419 & 426 & 1012 & 288 & 371 & 505 & 356 & 128 & 189 & 470 & 496 \\
\hline $\mathrm{Blog}$ & 282 & 96 & 171 & 50 & 88 & 193 & 195 & 208 & 100 & 221 & 201 & 103 & 183 & 283 & 422 & 247 \\
\hline Micro Blog & 144 & 67 & 134 & 19 & 42 & 118 & 106 & 146 & 59 & 107 & 190 & 67 & 77 & 119 & 327 & 186 \\
\hline
\end{tabular}

\section{Data Collection}

In order to prevent respondent fraud and ensure quality of panel data, a series of real-time checkpoints were required. New panel registrants had to pass all checkpoints when completing the panel registration survey. Registrants who failed any of the checks are unable to join the panel. The checkpoints used are provided in Table 3 (below).

Table 3. Real-Time Data Checkpoints

\begin{tabular}{|l|l|}
\hline Proxy Detection & Detect a proxy server used to mask the registrant's true IP address and past fraudulent activity \\
\hline IP GeoFencing & $\begin{array}{l}\text { Locates the registrant's country of origin through his/her IP address and determines their eligibility } \\
\text { for registration based on country-specific rules }\end{array}$ \\
\hline $\begin{array}{l}\text { Postal Address } \\
\text { Verification }\end{array}$ & $\begin{array}{l}\text { Verify the registrant's postal address and zip/postal codes against a current country-specific address } \\
\text { directory }\end{array}$ \\
\hline CAPTCHA & Prevent automated programs from joining our site through a challenge-response test \\
\hline $\begin{array}{l}\text { Email Address } \\
\text { Verification }\end{array}$ & $\begin{array}{l}\text { Query our database to ensure the email address is unique (all panelists must verify their email } \\
\text { address through a double opt-in registration process) }\end{array}$ \\
\hline
\end{tabular}

Once the panelists were registered, measures to identify and remove fraudulent survey data were taken through a series of quality checks. Respondents who did not participate in the survey to the best of their abilities were identified, and all survey answers they provided were removed from the final data. Poor survey takers were removed from the panel. Participant quality checks are provided in Table 4.

Table 4. Participant Quality Checks

\begin{tabular}{|l|l|}
\hline Respondent Engagement & $\begin{array}{l}\text { At the beginning of a survey, respondents must agree to provide honest, thoughtful } \\
\text { answers to each question }\end{array}$ \\
\hline Survey Speedsters & $\begin{array}{l}\text { Respondents who rushed through the survey are identified by comparing survey } \\
\text { completion times to the norm }\end{array}$ \\
\hline Grid Speedsters & $\begin{array}{l}\text { Respondents who rushed through grid questions are identified by comparing grid } \\
\text { completion times to the norm }\end{array}$ \\
\hline Trap Questions & $\begin{array}{l}\text { Survey questions with obvious answers can determine whether a respondent is fully } \\
\text { engaged with the survey }\end{array}$ \\
\hline Respondent Satisfaction & $\begin{array}{l}\text { At the end of a survey, feedback from respondents is gathered and assessed to help } \\
\text { determine the quality of the survey }\end{array}$ \\
\hline
\end{tabular}


Since the study is designed to analyze the behavior of people that have access to the internet, the large sample size provides a sample that is representative of the population of online users in each country. The measures taken during the data collection process ensure the validity of the respondents and the quality of their responses.

\section{Analysis}

Summary data is reported on positive responses to questions related to buy and sell activity for each of the five online social broadcast behaviors for active users. The questions are as follows:

\section{Sell Type}

- Have you used a blog to promote something?

- Have you used your social network profile to promote something?

- Have you uploaded a video to promote something?

- Have you uploaded a photo to promote something?

- Have you used a micro-blog to promote something?

Buy Type

- $\quad$ Have you used a blog to research or find products to buy?

- Have you used your social network profile to research or find products to buy?

- Have you viewed uploaded videos to research or find products to buy?

- Have you viewed uploaded photos to research or find products to buy?

- Have you used a micro-blog to research or find products to buy?

Active users are defined as respondents who have participated in the activity within the past thirty days. The summary data includes the percentage of respondents using each social broadcast behavior for selling activities (and buying activities) per country.

The first data analysis step is to group users into two populations. Group one $(n=37,689)$ is the modern industrialized or developed countries which include Australia, Canada, France, Germany, Italy, Japan, Netherlands, South Korea, Spain UK and the USA. Group two is the emerging countries $(n=19,630)$ which include Brazil, Russia, India, China, Malaysia and Mexico.

The second step, before comparing the proportions of the groups, is to run outlier tests to determine if any countries or panels could skew the results. The outlier test selected is the Grubbs' test, also called the ESD method (extreme studentized deviate) test. The Grubbs' test was run at a significance level of .01 and calculated the proportion of active users using each broadcast behavior to buy or sell something from both emerging vs developed populations. For each comparison group (i.e. SN used to sell) a test was run for the developed country population and another test for the emerging country population. Two developed country outliers were identified in the first wave of the panel for South Korea (Sell-SN) and the third wave of the panel for Japan (Buy-Video). Both outlier waves were removed from the analysis.

\begin{tabular}{|c|c|c|c|c|c|}
\hline Wave & $\begin{array}{c}\text { Emerging/Developed } \\
\text { (Country) }\end{array}$ & $\begin{array}{c}\text { Sample } \\
\text { Size }\end{array}$ & Behavior/Platform & $\begin{array}{c}\text { Grubbs' } \\
\text { Z Score }\end{array}$ & $\begin{array}{c}\text { Significant (p<.01) } \\
\text { Outlier? }\end{array}$ \\
\hline Wave 1 & $\begin{array}{c}\text { Developed } \\
\text { (South Korea) }\end{array}$ & 755 & Sell - SN & 3.58 & Yes \\
\hline Wave 3 & $\begin{array}{c}\text { Developed } \\
\text { (Japan) }\end{array}$ & 751 & Buy - Vid & 4.21 & Yes \\
\hline
\end{tabular}




\section{Descriptive Statistics - Developed (South Korea) - Sell Using Social Networking}

Mean:

SD:

\# of values:

Outlier detected?

Significance level:

Critical value of $Z$ :
0.0136

0.0129

33

Yes

0.01 (two-sided)

3.28581505962

$\begin{array}{ll}\text { Descriptive Statistics - Developed (Japan) - Buy Using Video Upload } \\ \text { Mean: } & 0.0136 \\ \text { SD: } & 0.0158 \\ \text { \# of values: } & 33 \\ \text { Outlier detected? } & \text { Yes } \\ \text { Significance level: } & 0.01 \text { (two-sided) } \\ \text { Critical value of Z: } & 3.28581505962\end{array}$

The third step is to consolidate reported motivational (sell or buy) usage of each social media tool by emerging and developed populations. All three waves are combined and the proportions for each country (rounded to the nearest percentage point) are averaged.

Step number four is to determine if the proportional differences (between the emerging and developed populations) are statistically significant to the point where they could not be explained by random chance. In order to make this determination, the data is analyzed using individual $\mathrm{Z}$ tests of the proportions.

The collective sample size for the developed country population is 36,183 (after the two outlier waves are removed). The collective sample size for the emerging country populations is 19,630 .

\section{RESULTS}

Table 1 shows that the percent of "active" users of both social networking and micro-blogging tools, in particular, are significantly greater in emerging countries vs developed nations. $\mathrm{Z}$ scores (two tailed) of 9.87 and 6.26 respectively are significant at the $\mathrm{p}<.01$ level. 
Table 1:

Percent Active Users Of Social Media Platforms For Sell Or Buy Activities In Developed Vs Emerging Countries

\begin{tabular}{|l|c|c|c|c|c|c|}
\hline \multirow{2}{*}{ TOOL } & \multicolumn{2}{|c|}{$\begin{array}{c}\text { DEVELOPED } \\
\text { COUNTRIES }\end{array}$} & \multicolumn{2}{c|}{$\begin{array}{c}\text { EMERGING } \\
\text { COUNTRIES }\end{array}$} & \multirow{2}{*}{ Z SCORE } \\
\cline { 1 - 5 } & $\begin{array}{c}\text { SELL OR BUY } \\
\text { MOTIVATION }\end{array}$ & SAMPLE & $\begin{array}{c}\text { SELL OR BUY } \\
\text { MOTIVATION }\end{array}$ & SAMPLE & $\begin{array}{c}\text { SICANCE } \\
\text { LEVEL }\end{array}$ \\
\hline SN & 0.99 & 36183 & $\mathbf{2 . 1 3}$ & 19630 & 9.87 & $\mathbf{0 . 0 1}$ \\
\hline MBLOG & 3.31 & 36183 & $\mathbf{4 . 4 0}$ & 19630 & 6.26 & $\mathbf{0 . 0 1}$ \\
\hline VIDEO & 2.41 & 36183 & 2.40 & 19630 & 0.07 & NS \\
\hline BLOG & 3.75 & 36183 & 4.00 & 19630 & 1.45 & NS \\
\hline PHOTO & 2.66 & 36183 & 2.70 & 19630 & 0.28 & NS \\
\hline
\end{tabular}

Looking at this data in a slightly different way, Table 2 shows that, when computing a ratio of sell to buy motivation for active users from emerging and developed countries, the data begin to show differential usage patterns. Emerging country micro-blog and video users have a significantly higher sell to buy ratio than their developed country counterparts $(\mathrm{Z}$ scores of 14.09 and $4.58 ; \mathrm{p}<.01)$. However, both the social networking and blogging sell to buy ratios are actually higher for developed country users than those from emerging nations ( $\mathrm{Z}$ scores 4.34 and $4.40 ; \mathrm{p}<.01)$.

Table 2: Active Social Media Platform Users Sell Vs Buy Activity In Developed Vs Emerging Countries

\begin{tabular}{|c|c|c|c|c|c|c|}
\hline \multirow[t]{2}{*}{ TOOL } & \multicolumn{2}{|c|}{$\begin{array}{c}\text { DEVELOPED } \\
\text { COUNTRIES }\end{array}$} & \multirow{2}{*}{$\begin{array}{c}\text { EMERGING } \\
\text { SELL/BUY } \\
\text { RATIO } \\
\end{array}$} & \multirow{2}{*}{$\begin{array}{r}\text { COUNTRIES } \\
\text { SAMPLE SIZE } \\
\end{array}$} & \multirow[t]{2}{*}{$\begin{array}{c}\text { McNEMAR } \\
\text { Z SCORE } \\
\text { (TWO TAILED) }\end{array}$} & \multirow[t]{2}{*}{$\begin{array}{c}\text { SIGNIFICANCE } \\
\text { LEVEL }\end{array}$} \\
\hline & $\begin{array}{c}\text { SELL/BUY } \\
\text { RATIO } \\
\end{array}$ & SAMPLE SIZE & & & & \\
\hline SN & 1.75 & 36183 & 1.29 & 19630 & 4.34 & 0.01 \\
\hline MBLOG & 1.72 & 36183 & 3.89 & 19630 & 14.09 & 0.01 \\
\hline VIDEO & 3.05 & 36183 & 3.80 & 19630 & 4.58 & 0.01 \\
\hline BLOG & 4.00 & 36183 & 3.28 & 19630 & 4.40 & 0.01 \\
\hline PHOTO & 2.26 & 36183 & 2.53 & 19630 & 1.98 & NS \\
\hline
\end{tabular}

Tables 3 and 4 show usage patterns driven by sell (Table 3) and buy (Table 4) motivation for developed and emerging country active users. The data clearly show that social networking and micro-blogging are the preferred sell platforms in emerging economies vs developed economies. Significant Z scores of 9.19 and 13.36 $(\mathrm{p}<.01)$ are caluclated for SN and MBLOG respectively.

Table 3: Developed Vs Emerging Countries - Using Social Media To Sell

\begin{tabular}{|c|c|c|c|c|c|c|}
\hline \multirow[t]{2}{*}{ TOOL } & \multicolumn{2}{|c|}{$\begin{array}{l}\text { DEVELOPED } \\
\text { COUNTRIES }\end{array}$} & \multicolumn{2}{|c|}{$\begin{array}{c}\text { EMERGING } \\
\text { COUNTRIES }\end{array}$} & \multirow[t]{2}{*}{$\begin{array}{c}\text { Z SCORE } \\
\text { (TWO TAILED) }\end{array}$} & \multirow[t]{2}{*}{$\begin{array}{c}\text { SIGNIFICANCE } \\
\text { LEVEL }\end{array}$} \\
\hline & SELL & SAMPLE SIZE & SELL & SAMPLE SIZE & & \\
\hline $\mathbf{S N}$ & 1.26 & 36183 & 2.40 & 19630 & 9.19 & 0.01 \\
\hline MBLOG & 4.19 & 36183 & 7.00 & 19630 & 13.36 & 0.01 \\
\hline VIDEO & 3.63 & 36183 & 3.80 & 19630 & 1.01 & NS \\
\hline BLOG & 6.00 & 36183 & 6.13 & 19630 & 0.61 & NS \\
\hline PHOTO & 3.68 & 36183 & 3.87 & 19630 & 1.12 & NS \\
\hline
\end{tabular}


With regards to using social media to buy something, Table 4 shows two significant differences: social networking and blogging are used more by active users in emerging economies over users in developed economies. $\mathrm{Z}$ scores of 10.74 and 3.19 ( $\mathrm{p}<.01)$ conclude that these differences are significant. Interestingly, while microblogging is used more to sell in emerging economies than in developed economies (Table 3), it also tends to be used more for buying something in the developed (vs emerging) countries ( $Z$ score, 5.05; $p<.01$ ).

Table 4: Developed Vs Emerging Countries - Using Social Media To Buy

\begin{tabular}{|l|c|c|c|c|c|c|}
\hline & \multicolumn{2}{|c|}{} & \multicolumn{2}{c|}{$\begin{array}{c}\text { EMERGING } \\
\text { COUNTIES }\end{array}$} & $\begin{array}{c}\text { Z SCORE } \\
\text { (TWO TAILED) }\end{array}$ & $\begin{array}{c}\text { SIGNIFICANCE } \\
\text { LEVEL }\end{array}$ \\
\hline & DEVELOPED & COUNTRIES & \multicolumn{2}{c|}{ SOMPLE SIZE } & & \\
\hline SN & BUY & SAMPLE SIZE & BUY & SAMPLE & 10.74 & $\mathbf{0 . 0 1}$ \\
\hline MBLOG & $\mathbf{2 . 4 3}$ & 36183 & 1.80 & 19630 & 5.05 & $\mathbf{0 . 0 1}$ \\
\hline VIDEO & 1.19 & 36183 & 1.00 & 19630 & 2.09 & NS \\
\hline BLOG & 1.50 & 36183 & $\mathbf{1 . 8 7}$ & 19630 & 3.19 & $\mathbf{0 . 0 1}$ \\
\hline PHOTO & 1.63 & 36183 & 1.53 & 19630 & 0.91 & NS \\
\hline
\end{tabular}

\section{DISCUSSION}

Table 5 summarizes and simplifies findings from the results section. It appears that there are differences in the way global users deploy social media tools when it comes to sell and buy activities. Key findings are briefly discussed by economy and then by social media tool.

\begin{tabular}{|c|c|c|c|c|c|c|c|c|c|}
\hline \multirow[t]{2}{*}{$\begin{array}{l}\text { SOCIAL MEDIA } \\
\text { PLATFORM }\end{array}$} & \multicolumn{4}{|c|}{$\begin{array}{c}\text { PREFERRED BY EMERGING } \\
\text { COUNTRIES }\end{array}$} & \multicolumn{4}{|c|}{$\begin{array}{c}\text { PREFERRED BY DEVELOPED } \\
\text { COUNTRIES }\end{array}$} & \multirow[t]{2}{*}{$\begin{array}{c}\text { NO } \\
\text { DIFFERENCE }\end{array}$} \\
\hline & SELL & $B U Y$ & $\begin{array}{c}B U Y \\
O R \\
S E L L\end{array}$ & $\begin{array}{c}S E L L / \\
B U Y \\
B I A S\end{array}$ & $S E L L$ & $B U Y$ & $\begin{array}{c}B U Y \\
O R \\
S E L L\end{array}$ & $\begin{array}{c}\text { SELL/ } \\
B U Y \\
B I A S\end{array}$ & \\
\hline Social Networking & $\mathrm{X}$ & $\mathrm{X}$ & $\mathrm{X}$ & & & & & $\mathrm{X}$ & \\
\hline Micro-blogging & $\mathrm{X}$ & & $\mathrm{X}$ & $\mathrm{X}$ & & $\mathrm{X}$ & & & \\
\hline Blogging & & $\mathrm{X}$ & & & & & & $\mathrm{X}$ & \\
\hline Video & & & & $\mathrm{X}$ & & & & & \\
\hline Photo & & & & & & & & & $\mathrm{X}$ \\
\hline
\end{tabular}

As can be seen from Tables 1-5, users from emerging economies like India, Brazil, and Mexico:

- $\quad$ use social networking and micro-blogging specifically, vs developed economies when the motivation is to sell or buy something

- $\quad$ use social networking and micro-blogging more to sell something vs developed economies

- $\quad$ use social networking and blogging more to buy something over developed economy users

- have a higher sell to buy usage ratio for micro-blogging and video than their developed country counterparts

Similarly, users from developed nations, like most of Europe, the U.S. and Australia:

- $\quad$ use micro-blogging more to buy something vs emerging countries

- $\quad$ have a higher social networking sell to buy usage ratio than users from emerging nations 
- $\quad$ have a higher blogging sell to buy usage ratio bias over emerging nations

From an overall social media vantage point, social networking and micro-blogging appear to be most preferred across the board. Social networking sites, like Facebook, are quite popular in emerging economies, regardless of whether the motivation for use is to sell, to buy or both. Micro-blogging tools, like Twitter, are distinctly preferred to sell something in the emerging economies, but preferred for buying activities in the developed nations.

Blogging is the preferred buy tool for emerging nations (over developed), and not surprising, has a higher sell to buy usage ratio for developed nations.

Video and photo uploading, were not used in any consistent, differential way between emerging and developed nations. The sell to buy ratio for video was higher for emerging economies, but the difference, while statistically significant, was not overwhelming from a practical perspective. There were no differences in sell or buy motivation for photo uploading tools, such as Flickr, across economies.

The above findings further elaborate and define usage patterns drawn from earlier studies from the same Trendstream global data (Jobs, 2011; Gilfoil and Jobs, 2011). They also provide preliminary guidance to marketers seeking to launch or continue global marketing eWOM campaigns to emerging or developed economies or to ad hoc users looking to buy online from global vendors.

While Jobs (2011) found that the ratio of micro-blogging (i.e. Twitter) to social networking (i.e. Facebook) usage rates for emerging economies were much higher than developed countries, he did not analyze usage motivation (i.e. what users were using the social media tools for). Nor did he study detailed usage patterns for social media tools beyond micro-blogging and social networking. Gilfoil and Jobs (2011) analyzed buy and sell motivation of users, but only evaluated country by country differences and only tangentially made references to divergent economies (developed vs developing) in their discussion section. They also focused on four social media platforms (excluding photo uploading) that key international market groups identified as significant for future consideration.

The value of the present study lies in its focus on the explosive emerging economies (juxtaposed to the developed, industrialized nations) and the preliminary mapping guidance that suggests which platforms are being used for which (sell/buy) activities in each type of economy.

It is important to consider, however, that the number of respondents actively engaged in buying and selling is generally a small percentage of the overall population of online users for each country. Therefore, a statistically significant result may, in some cases, not be substantial in practical terms. These relatively small usage numbers for some social media platforms in some countries are not terribly surprising if one considers that the tools are most likely still in the early adoption stages.

It is also important to note that while the analysis was done on a country by country basis in this study - it is certain that some buyers and sellers are conducting transactions across borders and not solely within country. However, given the pervasive trend of seller biased usage patterns (with exceptions noted), cross border activity does not appear to mitigate the findings.

\section{CONCLUSION}

Several conclusions can be taken away from this research investigation. First, similar to other findings, the Trendstream GWI data continue to suggest that eWOM is alive and well and that Web 2.0 social media platforms are viable mechanisms, for global marketers and consumers alike, to engage in eWOM activities. Many have suggested that this is the case and this follow up research supports this position.

In addition, there is strong evidence suggesting that the five social media behaviors/tools under investigation are being used differentially by participants in emerging vs developed economies. Emerging 
economies appear to be using the tools (in the aggregate) to sell something (vs to buy something) more than their counterparts in the developed world. This sell/buy disequilibrium was first discussed by Gilfoil and Jobs (2011) and validated in this follow up study.

Because of the different usage patterns observed in this study, one can conclude that it is helpful to map social media usage patterns to make better sense for sell-buy behaviors important to global marketers and ad hoc buyers - depending on which type of global economy they plan on conducting their business in. For example, while social networking and micro-blogging appear to be preferred for either sell or buy activities in emerging economies, micro-blogging is used preferentially for buy behaviors only in developed countries.

Finally, other longitudinal data need to be collected (especially on the motivational usage of these tools) if we are to complete any meaningful usage taxonomy for global users. It could be argued that we are still at the early stages of adoption for many of these platforms, that global usage patterns are likely to shift, and that other new technologies (Web 3.0?) are coming that will change the landscape, as we know it, even further.

\section{AUTHOR INFORMATION}

Dr. David M. Gilfoil earned his Ph.D. at Stevens Institute of Technology in Hoboken, NJ in 1983. Currently he is Director of the MBA program at DeSales University in Center Valley, PA. Dr. Gilfoil teaches Marketing, Management, Sales and Sales Management, Business Ethics, and Consumer Behavior. Prior to joining DeSales, he spent over 25 years in the telecom and semiconductor industries and has business experience in 40 countries in North America, South America, Europe, and Asia. E-mail: david.gilfoil@desales.edu

\section{REFERENCES}

1. Anderson, P. What is Web 2.0? Ideas, technologies and implications for education, in: JISC Technology and Standards Watch, Feb, 1-64., 2007

2. CMO.com. 2011 http://www.cmo.com/social-media/2011-cmos-guide-social-landscape\#ixzz1WQnhtWZI

3. Arminen, Leena "Using Social Media Strategically for Successful Buzz Marketing, Case: Spin Group". Thesis: Degree Programme in Business Management. Laurea University of Applied Sciences, Finland, May 2010.

4. Constantinides, E., Fountain S., "Web 2.0: Conceptual Foundations and Marketing Issues", Journal of Direct, Data and Digital Marketing Practice, Vol. 9, No. 3, pp. 231-244, 2008.

5. Constantinides, E., Romero, C.L. \& Gómez, M.A.. "Social media: a new frontier for retailers?" European Retail Research, 22(1), pp. 1-28. 2008

6. Fisher, Tia, "ROI in social media: A look at the arguments," Database Marketing \& Customer Strategy Management, Vol. 16, 3, 189-195, 2009, .

7. Forrester Research. US Interactive Marketing Forecast, 2009 To 2014 http://www.forrester.com/rb/Research/us interactive marketing forecast, 2009 to_2014/q/id/47730/t/2

8. Goldsmith, R.E., "Electronic Word-of-Mouth", in Khosrow-Pour, M. (Ed.), Encyclopedia of ECommerce, E-Government and Mobile Commerce, Idea Group Publishing, 2006.

9. Hartline, J.D., Mirrokni, V.S., and Sundararajan, M. "Optimal marketing strategies over social networks". Proceedings of the 17th International Conference on World Wide Web, pages 189-198, 2008.

10. Hennig-Thurau, T., Gwinner, K.P.,Walsh, G., \& Gremle, D.D.. "Electronic Word-of-Mouth via Consumeropinion Platforms: What Motivates Consumers to Articulate Themselves on the Internet?" Journal of Interactive Marketing, 18(1), 38-52.,2004

11. Hoegg, R.; Martignoni, R.; Meckel, M.; Stanoevska-Slabeva, K. "Overview of Business Models for Web 2.0 Communities, in: Proceedings of GeNeMe 2006 Conference, Dresden, Germany, 2006 http://www.alexandria.unisg.ch/Publikationen/31411

12. Hoffman, D. \& Fodor, M. "Can You Measure the ROI of Your Social Media Marketing?” MIT Sloan Management Review. 52(1), 41-49, Fall, 2010.

13. Jalilvand, M. R., Esfanani, S. S., and Samiei, N. "Electronic Word-of-Mouth: Challenges and Opportunities. Procedia Computer Science, 2011 - Elsevier 
14. Jansen, B., Zhang, M., Sobel, K., and Chowdury, A. "Twitter Power: Tweets as Electronic Word of Mouth." Journal of the American Society for Information Science and Technology, 2009.

15. Jobs, C. "A Comparative Analysis of the Adoption Rates of Social Networking and Micro-blogging Between Industrialized and Developing Nations". Journal of International Business Research, 2011

16. Jobs, C. and Gilfoil, D. "Hofstede's Cultural Dimensions as an Indicator of Adoption Rates of Social Networking and Micro-blogging between Industrialized and Developing Nations". Academy of Marketing Studies Journal, 2011

17. Ju, J.I., Lee, J.C., and Lee, K.J., "Ubiquitous Business Model by Seamless Integration of Photo and Location Information," IEEE Asia-Pacific Services Computing Conference, pp.1527-1532, 2008

18. Lee, M.K.O., Cheung, C.M.K., Lim, K.H. \& Sia, C.L., "Understanding Customer Knowledge Sharing In Web-Based Discussion Boards: An Exploratory Study", Internet Research, Vol. 16 No. 3, 2006

19. Leskovec, J., Adamic, L.A. and Huberman, B. A, "The dynamics of viral marketing," ACM Transactions on the Web, 1(1), 5, 2007.

20. Lewis, G. “Asymmetric Information, Adverse Selection and Online Disclosure: The Case of eBay Motors." The American Economic Review. Volume 101, Number 4, June 2011 , pp. 1535-1546(12)

21. Lieberman, M. and D. Montgomery, "First-mover advantages", Strategic Management Journal, Volume 9, Summer 1988.

22. O'Reilly T., What is Web 2.0? http://www.oreillynet.com/pub/a/oreilly/tim/news/2005/09/30/what-is-web20.html

23. Parise, S., Guinan, P.J. "Marketing using Web 2.0", in: Proceedings of the $41{ }^{\text {st }}$ Hawaii International Conference on System Sciences", 2008

24. Piskorski, M., \& McCall, T. "Vision Statement: Mapping the Social Internet." Harvard Business Review 88, nos. 7-8 (July - August 2010).

25. Potts, J D., Hartley, J., Banks, J. A., Burgess, J., E, Cobcroft, R. S., Cunningham, S., D., and Montgomery, L. "Consumer Co-creation and Situated Creativity". Industry and Innovation, 15(5). pp.459-474., 2008

26. Ratchford, B.T., Talukdar, D. \& Lee, M.-S., "A Model of Consumer Choice of the Internet As An Information Source", International Journal of Electronic Commerce, Vol. 5, No. 3, 2001, pp.7-22.

27. Richins, M.L., \& Root-Shaffer, T. "The Role of Involvement and Opinion Leadership in Consumer Wordof-Mouth: An Implicit Model Made Explicit. Advances in Consumer Research, 15, 32-36. 1988.

28. Scott, D. M. The New Rules of Marketing and PR: How to Use Social Media, Blogs, News Releases, Online Video, and Viral Marketing to Reach Buyers Directly, John Wiley and Sons, 2010288 pages.

29. Subramani, M. \& Rajagopalan, B. "Knowledge-Sharing and Influence in Online Social Networks via Viral Marketing”. Communications of the ACM, Vol. 46 Issue 12, p300-307, Dec, 2003.

30. Thackeray, R \& Neiger, B. \& .Hanson, C. \& McKenzie, J "Enhancing Promotional Strategies Within Social Marketing Programs: Use of Web 2.0 Social Media”., Health Promotion Practice; Vol. 9 Issue 4, p338-343, 6p, October 2008,

31. TopRank (2011) http://www.toprankblog.com/2010/07/seo-tops-digital-marketing-2011/

32. Van der Lans, R., Van Bruggen, G., Eliashberg, J., and Wierenga, B. "A Viral Branching Model for Predicting the Spread of Electronic Word of Mouth, Marketing Science, Vol. 29, pp. 348-365, 2010.

33. Weber, L. 2009. Marketing to the Social Web: how digital customer communities build your business. 2 nd Edition. Hoboken, NJ: John Wiley \& Sons. 


\section{APPENDIX A:}

Percent Active Users Of Social Networking, Micro-Blogging, Video, And Blogging Platforms For Sell Vs Buy Activities - Developed Countries

\begin{tabular}{|c|c|c|c|c|c|c|c|c|c|c|c|}
\hline & & SELL-sn & SELL-mb & SELL-vid & SELL-blog & SELL-photd & BUY-sn & BUY-mb & BUY-vid & BUY-blog & BUY-photo \\
\hline wave 1 & Australia & $1 \%$ & $0 \%$ & $1 \%$ & $3 \%$ & $3 \%$ & $0 \%$ & $0 \%$ & $1 \%$ & $0 \%$ & $1 \%$ \\
\hline wave 2 & Australia & $1 \%$ & $2 \%$ & $3 \%$ & $8 \%$ & $5 \%$ & $0 \%$ & $2 \%$ & $0 \%$ & $0 \%$ & $0 \%$ \\
\hline wave 3 & Australia & $1 \%$ & $4 \%$ & $5 \%$ & $3 \%$ & $5 \%$ & $0 \%$ & $3 \%$ & $0 \%$ & $2 \%$ & $2 \%$ \\
\hline wave 1 & Canada & $1 \%$ & $0 \%$ & $5 \%$ & $10 \%$ & $4 \%$ & $0 \%$ & $0 \%$ & $1 \%$ & $0 \%$ & $0 \%$ \\
\hline wave 2 & Canada & $1 \%$ & $6 \%$ & $2 \%$ & $7 \%$ & $3 \%$ & $0 \%$ & $1 \%$ & $1 \%$ & $2 \%$ & $1 \%$ \\
\hline wave 3 & Canada & $1 \%$ & $4 \%$ & $6 \%$ & $8 \%$ & $3 \%$ & $1 \%$ & $3 \%$ & $2 \%$ & $0 \%$ & $1 \%$ \\
\hline wave 1 & France & $0 \%$ & $0 \%$ & $3 \%$ & $9 \%$ & $2 \%$ & $1 \%$ & $0 \%$ & $2 \%$ & $2 \%$ & $1 \%$ \\
\hline wave 2 & France & $1 \%$ & $0 \%$ & $1 \%$ & $10 \%$ & $2 \%$ & $1 \%$ & $0 \%$ & $1 \%$ & $0 \%$ & $1 \%$ \\
\hline wave 3 & France & $1 \%$ & $10 \%$ & $8 \%$ & $13 \%$ & $5 \%$ & $2 \%$ & $0 \%$ & $0 \%$ & $2 \%$ & $1 \%$ \\
\hline wave 1 & Germany & $1 \%$ & $0 \%$ & $6 \%$ & $5 \%$ & $4 \%$ & $1 \%$ & $0 \%$ & $2 \%$ & $2 \%$ & $2 \%$ \\
\hline wave 2 & Germany & $1 \%$ & $7 \%$ & $2 \%$ & $6 \%$ & $4 \%$ & $0 \%$ & $0 \%$ & $1 \%$ & $2 \%$ & $2 \%$ \\
\hline wave 3 & Germany & $0 \%$ & $5 \%$ & $2 \%$ & $5 \%$ & $5 \%$ & $0 \%$ & $5 \%$ & $2 \%$ & $5 \%$ & $1 \%$ \\
\hline wave 1 & Italy & $2 \%$ & $0 \%$ & $4 \%$ & $5 \%$ & $5 \%$ & $2 \%$ & $0 \%$ & $3 \%$ & $2 \%$ & $1 \%$ \\
\hline wave 2 & Italy & $2 \%$ & $4 \%$ & $4 \%$ & $6 \%$ & $5 \%$ & $1 \%$ & $1 \%$ & $1 \%$ & $3 \%$ & $2 \%$ \\
\hline wave 3 & Italy & $3 \%$ & $6 \%$ & $8 \%$ & $7 \%$ & $6 \%$ & $1 \%$ & $5 \%$ & $3 \%$ & $2 \%$ & $2 \%$ \\
\hline wave 1 & Japan & $4 \%$ & $0 \%$ & $4 \%$ & $4 \%$ & $5 \%$ & $2 \%$ & $0 \%$ & $4 \%$ & $2 \%$ & $3 \%$ \\
\hline wave 2 & Japan & $3 \%$ & $7 \%$ & $0 \%$ & $8 \%$ & $6 \%$ & $0 \%$ & $3 \%$ & $0 \%$ & $1 \%$ & $4 \%$ \\
\hline wave 3 & Japan & $2 \%$ & $4 \%$ & $5 \%$ & $7 \%$ & $0 \%$ & $1 \%$ & $4 \%$ & $0 \%$ & $2 \%$ & $3 \%$ \\
\hline wave 1 & Netherlands & $1 \%$ & $0 \%$ & $4 \%$ & $3 \%$ & $2 \%$ & $0 \%$ & $0 \%$ & $0 \%$ & $0 \%$ & $3 \%$ \\
\hline wave 2 & Netherlands & $0 \%$ & $0 \%$ & $1 \%$ & $4 \%$ & $3 \%$ & $0 \%$ & $4 \%$ & $0 \%$ & $0 \%$ & $2 \%$ \\
\hline wave 3 & Netherlands & $1 \%$ & $0 \%$ & $1 \%$ & $0 \%$ & $3 \%$ & $1 \%$ & $0 \%$ & $0 \%$ & $4 \%$ & $2 \%$ \\
\hline wave 1 & South Korea & $0 \%$ & $0 \%$ & $5 \%$ & $6 \%$ & $4 \%$ & $0 \%$ & $0 \%$ & $1 \%$ & $1 \%$ & $2 \%$ \\
\hline wave 2 & South Korea & $3 \%$ & $6 \%$ & $4 \%$ & $4 \%$ & $3 \%$ & $2 \%$ & $3 \%$ & $1 \%$ & $3 \%$ & $2 \%$ \\
\hline wave 3 & South Korea & $0 \%$ & $0 \%$ & $0 \%$ & $0 \%$ & $0 \%$ & $0 \%$ & $0 \%$ & $0 \%$ & $0 \%$ & $0 \%$ \\
\hline wave 1 & Spain & $0 \%$ & $0 \%$ & $3 \%$ & $6 \%$ & $2 \%$ & $0 \%$ & $0 \%$ & $0 \%$ & $1 \%$ & $2 \%$ \\
\hline wave 2 & Spain & $0 \%$ & $1 \%$ & $4 \%$ & $7 \%$ & $3 \%$ & $1 \%$ & $4 \%$ & $1 \%$ & $1 \%$ & $1 \%$ \\
\hline wave 3 & Spain & $2 \%$ & $6 \%$ & $7 \%$ & $3 \%$ & $4 \%$ & $1 \%$ & $5 \%$ & $1 \%$ & $1 \%$ & $1 \%$ \\
\hline wave 1 & UK & $1 \%$ & $0 \%$ & $5 \%$ & $7 \%$ & $4 \%$ & $1 \%$ & $0 \%$ & $1 \%$ & $2 \%$ & $1 \%$ \\
\hline wave 2 & UK & $0 \%$ & $3 \%$ & $2 \%$ & $6 \%$ & $4 \%$ & $1 \%$ & $1 \%$ & $1 \%$ & $2 \%$ & $1 \%$ \\
\hline wave 3 & UK & $1 \%$ & $5 \%$ & $3 \%$ & $5 \%$ & $3 \%$ & $1 \%$ & $5 \%$ & $3 \%$ & $0 \%$ & $2 \%$ \\
\hline wave 1 & USA & $2 \%$ & $0 \%$ & $2 \%$ & $5 \%$ & $2 \%$ & $0 \%$ & $0 \%$ & $1 \%$ & $1 \%$ & $1 \%$ \\
\hline wave 2 & USA & $1 \%$ & $5 \%$ & $3 \%$ & $8 \%$ & $2 \%$ & $1 \%$ & $1 \%$ & $1 \%$ & $1 \%$ & $2 \%$ \\
\hline wave 3 & USA & $1 \%$ & $3 \%$ & $3 \%$ & $4 \%$ & $3 \%$ & $1 \%$ & $1 \%$ & $2 \%$ & $2 \%$ & $2 \%$ \\
\hline & Mean & $1.26 \%$ & $4.19 \%$ & $3.63 \%$ & $6.00 \%$ & $3.68 \%$ & $0.72 \%$ & $2.43 \%$ & $1.19 \%$ & $1.50 \%$ & $1.63 \%$ \\
\hline
\end{tabular}

*Outliers removed from Wave 3 Japan (Video) and Wave 1 South Korea (SN) 


\section{APPENDIX B:}

Percent Active Users Of Social Networking, Micro-Blogging, Video, And Blogging Platforms For Sell Vs Buy Activities - Emerging Countries

\begin{tabular}{|l|c|c|c|c|c|c|c|c|c|c|c|}
\hline & & SELL-sn & SELL-mb & SELL-vid & SELL-blog & SELL-photo & BUY-sn & BUY-mb & BUY-vid & BUY-blog & BUY-photo \\
\hline wave 1 & Brazil & $2 \%$ & $0 \%$ & $2 \%$ & $10 \%$ & $5 \%$ & $1 \%$ & $0 \%$ & $1 \%$ & $3 \%$ & $2 \%$ \\
\hline wave 2 & Brazil & $4 \%$ & $9 \%$ & $5 \%$ & $8 \%$ & $9 \%$ & $0 \%$ & $2 \%$ & $2 \%$ & $1 \%$ & $2 \%$ \\
\hline wave 3 & Brazil & $3 \%$ & $10 \%$ & $6 \%$ & $12 \%$ & $4 \%$ & $1 \%$ & $1 \%$ & $2 \%$ & $2 \%$ & $3 \%$ \\
\hline wave 1 & China & $1 \%$ & $0 \%$ & $0 \%$ & $1 \%$ & $2 \%$ & $5 \%$ & $0 \%$ & $0 \%$ & $1 \%$ & $1 \%$ \\
\hline wave 2 & China & $2 \%$ & $3 \%$ & $1 \%$ & $2 \%$ & $2 \%$ & $3 \%$ & $2 \%$ & $1 \%$ & $2 \%$ & $1 \%$ \\
\hline wave 3 & China & $1 \%$ & $2 \%$ & $2 \%$ & $2 \%$ & $2 \%$ & $2 \%$ & $1 \%$ & $2 \%$ & $2 \%$ & $2 \%$ \\
\hline wave 1 & India & $4 \%$ & $0 \%$ & $3 \%$ & $7 \%$ & $3 \%$ & $1 \%$ & $0 \%$ & $1 \%$ & $3 \%$ & $2 \%$ \\
\hline wave 2 & India & $3 \%$ & $9 \%$ & $3 \%$ & $5 \%$ & $4 \%$ & $1 \%$ & $3 \%$ & $1 \%$ & $2 \%$ & $1 \%$ \\
\hline wave 3 & India & $2 \%$ & $10 \%$ & $7 \%$ & $9 \%$ & $3 \%$ & $2 \%$ & $2 \%$ & $1 \%$ & $3 \%$ & $3 \%$ \\
\hline wave 3 & Malaysia* & $0 \%$ & $0 \%$ & $0 \%$ & $0 \%$ & $0 \%$ & $0 \%$ & $0 \%$ & $0 \%$ & $0 \%$ & $0 \%$ \\
\hline wave 1 & Mexico & $2 \%$ & $0 \%$ & $5 \%$ & $6 \%$ & $4 \%$ & $2 \%$ & $0 \%$ & $1 \%$ & $2 \%$ & $1 \%$ \\
\hline wave 2 & Mexico & $3 \%$ & $7 \%$ & $6 \%$ & $8 \%$ & $6 \%$ & $1 \%$ & $1 \%$ & $1 \%$ & $1 \%$ & $0 \%$ \\
\hline wave 3 & Mexico & $4 \%$ & $8 \%$ & $7 \%$ & $9 \%$ & $6 \%$ & $1 \%$ & $0 \%$ & $0 \%$ & $0 \%$ & $1 \%$ \\
\hline wave 1 & Russia & $1 \%$ & $0 \%$ & $4 \%$ & $4 \%$ & $3 \%$ & $1 \%$ & $0 \%$ & $1 \%$ & $2 \%$ & $2 \%$ \\
\hline wave 2 & Russia & $2 \%$ & $5 \%$ & $3 \%$ & $4 \%$ & $3 \%$ & $3 \%$ & $4 \%$ & $0 \%$ & $3 \%$ & $1 \%$ \\
\hline wave 3 & Russia & $\mathbf{2} \%$ & $\mathbf{7} \%$ & $3 \%$ & $5 \%$ & $2 \%$ & $2 \%$ & $2 \%$ & $1 \%$ & $1 \%$ & $1 \%$ \\
\hline & & & & & & & & & & & \\
\hline & Mean & $\mathbf{2 . 4 0} \%$ & $\mathbf{7 . 0 0} \%$ & $\mathbf{3 . 8 0} \%$ & $\mathbf{6 . 1 3 \%}$ & $\mathbf{3 . 8 7 \%}$ & $\mathbf{1 . 8 6 \%}$ & $\mathbf{1 . 8 0} \%$ & $\mathbf{1 . 0 0 \%}$ & $\mathbf{1 . 8 7 \%}$ & $\mathbf{1 . 5 3 \%}$ \\
\hline
\end{tabular}

*Missing data 